\title{
Complications of Translating the Meanings of the Holy Qur'an at Word Level in the English Language in Relation to Frame Semantic Theory
}

\author{
Asjad Ahmed Saeed Balla ${ }^{1}$, Ahmed Gumaa Siddiek ${ }^{2 *}$ \\ ${ }^{1}$ Al-Aflaj-Prince Sattam University, KSA and Gadarif University, Sudan \\ ${ }^{2}$ Al-Zaeem Al-Azhari University, Sudan and Shaqra University, KSA
}

Corresponding Author: Ahmed Gumaa Siddiek, E-mail: ssiddiekk@gmail.com

\section{ARTICLE INFO}

\section{Article history}

Received: July 08, 2017

Accepted: October 05, 2017

Published: October 31, 2017

Volume: 8 Issue: 5

Advance access: October 2017

Conflicts of interest: None

Funding: None

\section{Key words:}

Quran,

Islam,

Translation,

Lexical Choice,

Cultural Background,

Linguistic Background

\begin{abstract}
The present study is an attempt to investigate the problems resulting from the lexical choice in the translation of the Holy Qur'an to emphasize the importance of the theory of "Frame Semantics" in the translation process. It has been conducted with the aim of measuring the difference in concept between the two languages Arabic and English. In order to find out this difference two words have been chosen from the Qur'an to see how the different English frames can affect the translation of the Holy Qur'an. In addition to that the paper aims to reveal the strategies used by translators to avoid such effect. We also intended to see which factors that can mostly affect the translation of the Qur'an: the linguistic background or the cultural knowledge. Four hypotheses were coined to deal with the difference in frame knowledge (conception) between Arabic and English. The analysis of the data showed that the linguistic background contributed more to the translators' ability than the cultural knowledge. A rank ordering for the five translations performed in the present study resulted in that the first rank (completely appropriate) was assigned to Yusuf Ali's translation and the second position was booked by Pickthall's translation.
\end{abstract}

\section{INTRODUCTION}

\section{The Context of the Problem}

The need for the interpretation and the translation of the meanings of the Qur'an was a natural result of the widespread of Islam all over the world. The translation of the Qur'an into English in particular, is regarded important, as English has become a universal means of communication, as well a medium of instructions in many educational environments. The need for the translation and interpretation of the Qur'an is not a recent need or a recent practice. It dated back to the early time of Prophet Mohammed (peace be upon him) when his companion asked about the meanings of some words and verses of the Holy Book.

The importance of translating the meanings of the Holy Qur'an comes from the fact that the Qur'an is the source of Islam that spread out all over the world and it is truly a divine book full of wisdom, teaching and great values. The need for understanding the Qur'an and Islam at the present time resulted from the conflict between Islamic Faith and other religions. There are two views of Islamic scholars about the translation of the Qur'an. The first group think that the Qur'an is untranslatable, while the second believes that the translation should not be literal translation of the Verses. It should focus on translating the meaning of the text or the concept intended by the specific verse. Therefore the translation - in this case - will be seen as some sort of explanation or interpretation (Tafseer: تفسير) of the Quranic Text.

\section{Aim of the Study}

The present study is an attempt to investigate some lexical problems that come up due to inappropriate lexical choice in the translations of the Qur'an according to the frame semantics theory as one good way to achieve better translation. The study tries to discover the differences between Arabic and English languages as whether different frames can cause problems in the translation of the Holy Qur'an. In addition, the study tries to point out the strategies used by translators to avoid such problems and which factor: the linguistic background or the cultural knowledge has greater influence on translating the Quranic text.

\section{Objectives of the Study}

This study attempts to look at the translation of Qur'an from its original Arabic Text into English and investigate the lexi- 
cal choice through working out on certain words which have been chosen from Quranic Verses and exposed to linguistic 'Frame Semantics' theory, as a way for better translation. The study tries to discover if there are differences in frame knowledge between Arabic and English by selecting special words. The study also tries to find out whether these English frames can cause a problem in the translation of the Qur'an. The Qur'an is the source of all Islamic Teachings, Rules and Values. And we can see now the great need for translating the Qur'an; as the number of non-Arabic Muslim speakers is increasing all over the world. These believers need to understand their religion to assimilate its valuable teachings, and then help others to adopt the Islamic belief, by giving good models in practice. It is hoped that the results of this study will contribute to professional improvement in the translation of the Holy Book.

\section{Hypotheses}

The differences in conception (frames knowledge) between (Arabic and English) can affect the translation process of the Qur'an. Arabic speakers like English speakers have got their own frame knowledge which is governed by the linguistic and social factors. The difference between the two frames means that there is a possibility of making the readers' understanding be affected, as the similarities of the frames may lead to easy translation and more understanding between the two communities.

\section{Hypothesis 1}

1-There are differences in conceptions (frame knowledge) between Arabic and English languages. Sometimes single lexical items in English vocabulary may have many meanings that can be used according to the context. This will make it hard for the translator to get the suitable choice, as each meaning can be used in different context in Arabic to describe a particular lexeme. This may lead to some problems in getting the target meaning through the translation process, specially the translation of the Quranic texts.

\section{Hypothesis 2}

The different English frames lead to problems in the translation of the Holy Qur'an. The translator can encounter a variety of choices to one lexical item that $\mathrm{s} / \mathrm{he}$ intends to translate. This can make her/him choose the wrong or inappropriate lexical choice which may affect the quality of the translation. Then the best way is to adopt some strategies to avoid possibility of the wrong choice.

\section{Hypothesis 3}

There are some strategies that translators use to overcome these problems. Choosing a suitable lexical item in the translation process depends on a lot of factors such as linguistic background, social factors, and cultural knowledge and so on. This can help translators to choose the suitable lexical item. From this idea comes the fourth hypothesis of this study.

\section{Hypothesis 4}

There is/are factor/s that contribute/s more than others to the translators' ability and determine his/her choice of one specific lexeme (e.g. linguistic background/cultural knowledge/ difference in linguistic systems etc...).

\section{Significance of the Study}

The importance of translating the Holy Qur'an into other languages is a practical need for some Muslim believers. It is as well a practical need for the non-Muslim to read and listen to the word of Allah. It is supposed to be the duty of every Muslim-man or woman-to help spread the CALL (البلاغ المبين) of Islam to reach all people on earth. Thus, a good translation is needed to help non-Arabic speakers and non-Arabic Muslim speakers as well. A great benefit will reach other communities that hold different faith; then it will allow them a good chance to understand the Qur'an, as the main source of Islamic Religion. This will also be one practical step towards setting up a dialogue to better understanding between Muslims and non-Muslims communities, to secure global peace and mutual human feelings. The study may add additional values to other fields such as sociolinguistics, psycholinguistics and theoretical linguistics as well.

\section{RELEVANT LITERATURE}

\section{Lexical Semantics}

Lexical semantics is an important branch of linguistic semantics. It is the study of what words mean and how they are related to each other with respect to their meanings. According to Geeraerts (1992), there are four main stages in the history of lexical semantics, which are: (1) 'pre-structuralist', (2) 'structuralist and neostructuralist', (3) 'generativist and neogenerativist', and (4) the cognitive semantics. We are here in no good position to go through details of the history of lexical semantics, as any reference about semantics would give satisfactory knowledge to the keen reader. But in a nutshell we can quote Geeraerts (2017), that the history of lexical semantics is characterized by a succession of different theoretical approaches that are related by lines of similarity and extrapolation as well as mutual opposition. As a basic underlying distinction, Geeraerts suggests singling out the contrast between an encyclopaedist approaches on the one hand, and a more restrictive approach on the other.

\section{Theories of Meaning}

In the past philosophers used to support other theories with the theories of meaning such as the knowledge theory and the definition of right and wrong that depends on observation. Recently they have understood the value of 'meaning' theories, not only to support other theories, but also for comprehending different language uses (Lehrer 1970).

Linguists studied and illustrated the way that people communicate. Accordingly, they have recognized that theories of 'meaning' are important in understanding how speakers go about communicating a message. Linguistically, sentences 
can be categorised as either meaningful or meaningless, and a sentence may have a peculiar meaning in some context, or be meaningful but having more than one interpretation in other context as in, for example, "All spinsters are married to handsome men" (Lehrer 1970:9). The meaning of a sentence depends on a lot of factors like: "Words themselves, setting of utterance, the identity of the speakers, the place where they come from and other kinds of non-linguistic information contribute to the meaning of the sentence" (Lehrer 1970:10).

Thus, the way that we utter the words and the background of the speaker beside their environment all influence the meaning of the sentence. For instance, the meaning of a "cupful of flour" is "ten ounces" in Britain while it is "eight ounces" in the United States. Additional factors like beliefs, cultural norms and shared knowledge can affect the meaning and they need to be somehow included into a theory of linguistics meaning (ibid).

The relationship between words on the one hand and grammar on the other, according to (Lehrer 1970:12), has some problems for instance, the proper size of the unit that can be used for semantic analysis small or long. Another problem is how to distinguish senses of words? For example, in one dictionary a fish can be defined as "legless water animal with a particular shape", whilst, in another dictionary it could be defined as a more limited class of legless water animal which has gills, lays eggs and so forth.

Lehrer asks whether we can say there are two different meanings of the word 'fish'? Similarly, can we give "eat" different meanings if we refer to different types of foods, such as, spaghetti and ice cream, simply because there are different ways of eating these foods (Lehrer 1970:12).

Moreover, it is difficult to differentiate between words that have the same sound but different senses. For example, the word "horn" has two meanings; (1) musical instrument (2) a part of an animal. There is a connection between the meanings, which is that a horn is part of an animal that is used as a musical instrument (Alston 1970). In this case, is it two words with different meaning or one word with different senses?

\section{Semantics Fields and Translation}

The fields are called "semantic fields" such as the field of 'Speech' and all the words under it called 'lexical set' for example 'verbs of speech' such as 'speak' and 'say' and more specifically 'murmur' and 'whisper'. The majority of the languages have equivalents for the general meaning of words such as 'speak' and 'say' meanwhile it becomes more difficult in specific ones (Baker 1992:18). Semantic fields help the translator to understand the value of the word in the language system and to expand the tactic he/she uses to deal with non-equivalence. Besides, it gives the translator the awareness of similarity and differences between the source and the target language.

Baker (1992:20) defines non-equivalence at word level as "the target language has no direct equivalent for a word which occurs in the source text". (ibid)

Many factors influence non-equivalence, the language nature beside the context and the purpose of the translation.
For instance, what is culture-specific concept? These concepts can be totally different in the source and target culture, e.g. the word 'privacy' in English which cannot be understood in many different other cultures (Baker, 1992). Another example is given by Albusairi (2000) like the word 'subhiya' or 'shaila' which stand for certain Sudanese marriage concepts.

Moreover, sometimes a concept in the source language can be understood in the target one but it is not lexicalized. For instance, the word 'standard' is an adjective can be understood in Arabic but it has not got an equivalent (Baker,1992:21). The lack of specific terms can be another non-equivalence problem for example, the field 'house' in English has got a lot of words under it like 'cottage', 'croft', 'lodge'... which do not have exact equivalents in many other languages (Baker,1992:23). Another important part of this area of semantics is the relation between the lexis themselves that is known as 'Sense Relations'. (ibid)

\section{Frame Semantics}

Frame Semantics is a scientific attempt to understand and get the meaning of a word through investigating its relation to the frame that it belongs to (Cheong 2000). Fillmore (1977a) describes frame semantics as "meanings are relativized to scenes".

According to Fillmore (1985:231) understanding frame semantics needs understanding the "relationship between linguistic context and the interpreters' full understanding of the texts in their context". This can be explained by using the following example from Fillmore (1977c): Mark and Mike are identical twins. They are in the hospital; each one is sitting in his bed inside his room in the same position. A nurse walks beside Mark's room she says, "I see that Mark is able to sit up now. While she says "I see that Mike is able to sit down now", when she comes across Mike's room. Thus the nurse's remarks can be interpreted according to the hospital scenes and frames by relativizing the meaning of her comments to the relevant scenes.

In other words, the translator cannot translate effectively unless he understands the word, its meaning, and the frame which it belongs to. For this reason frame semantics can be suitable for improving the translation (Cheong 2000).

Getting a meaning of a word can be easily done if the words are related to their background frame (Cheong 2000). Two sub-categories of frames are categorized by Fillmore (1965:231-233) who says, "some frames are undoubtedly innate in the sense that they appear naturally and unavoidably in the cognitive development of every human...others are learned through experience or training (e.g. knowledge of artefacts and social institution)."

\section{Summary}

So far, we have discussed lexical semantics and three theories of meaning from different perspectives. We have discussed theoretical background on field semantics and sense relations. Collocation plays role in the discussion and how it is essential for getting the meaning of words. Moreover, we 
have investigated frame semantic theory as a tool in finding good and proper equivalents of the meanings of words and expressions. Getting appropriate alternatives of the meaning of the words can facilitate and achieve good translation and positive communication.

\section{Lexical and Morphological Challenges in the Translation of the Holy Qur'an:}

There are many translations of the Qur'an into other languages. When the translator tries to reproduce the meaning of a text into another language, this may change the original meaning. Consequently, translations of the Qur'an were traditionally refused by Muslim scholars. Abu Hanifah (the famous Muslim scholar) did not permit reading the opening chapter (alfatiha) in any form of translation and confirmed that the verses of the Qur'an should be read in Arabic in the prayer for all Muslims (Arabic or non-Arabic), Raof (2001).

Accordingly, it is believed that all translations are inadequate and that an acceptable translation is one that explains the significance of the Quranic verses (Tony 1980:49). Abdelwali (2007) suggests that "The Qur'an is artistically constructed and strongly rhetorical in comparison with ordinary prose". This makes it unique and distinguishable from other Arabic prose, Raof (2001).

In a survey reported by Abdelwali (2007) of Qur'an translations into English, the results showed that the majority of the translators ignore the idiosyncrasies and prototypical features of the Qur'an text, while they care for communicating the message. That is to say they do not pay attention to its special features as a unique Arabic Text.

Each language has its own semantic features which can be more specific than in other languages. (Abdelwali 2007).

This specificity can be realized either through lexemes or the morphological system of the language. On the lexeme level English can be semantically more precise than Arabic, for example in describing certain military actions. The words "bombardment" and "shelling" would be translated in Arabic as qasf bil midfa 'iyya,(قذف بالمدفعية) and qasf bit Ta 'iraat (قذف بالطائرات), respectively. However, both of these words can have the same meaning in Arabic unless more words are added through paraphrasing to give the meaning of either 'bombardment' or 'shelling'.

According to (Abdelwali 2007), Arabic can be more accurate in grammatical meanings expressed by certain morphemes, which require some sort of paraphrasing to translate them into English. The verb patterns in Arab represent a framework in showing the subtleness of the meaning of the words. This can be shown in the following verses:

(1) Nazzala'alayka-1-kittab bil-Haqqi muSaddiqan limma bayna yadayhi wa'anzala t-tawraat wal-injiiil.

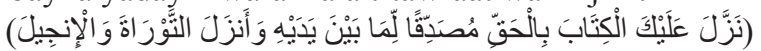

This is translated as follows:

"It is He who sent down to you (step by step) in truth, the book, confirming what went before it, and He sent down the law (of Moses) and the Gospel (of Jesus) (3:3) (Yusuf Ali:121). "nazzala" نزل indicates a piecemeal revelation of the Qur'an as well as a repetition of an action (which, in this case, lasted for 23 years). Meanwhile, “anzala" أنزل signifies the revelation all at once. Furthermore, it shows the difference between the piecemeal revelation and the revelation of the Torah and Gospel (Abdelwali 2007).

Another example can be shown here:

(2) Huwal-ladhi ja'la sh-shamsa Diyaa'an wal qamara nurran

\section{"هو الذى جعل الثمس ضياءآ والقمر نور آ "(10:5)}

Its translation is as follows: "It is He who made the Sun to be shining glory and the moon to be a light" (Ali, 983:484). The words “Diyaa'an' (ضياءآ) and "Nuuran" (نور)), indicate different features. The former means "the generation of heat", and "not shining glory," whilst the latter means "no generation of heat but light only". Moreover, "Diyaa' indicates that the Sun gives out its own light but the moonlight is a reflection of its light as signified by "Nuuran." On the other hand, a word like "duuni" is difficult to translate as well as paraphrase: (3) Qual'ud'uul-ladhiina za'amtum min duuni 1-laahi.

\section{"قل ادعو الذين زعتم من دون الله"(34:22)}

The above is translated as follows: "Say: appeal to those whom you claim to instead of God" Irving (1985:238). Duuni is variously translated as "dignity"," might" and "there is nothing above or equal to Him". Accordingly, the meaning here requires explanatory notes from the translators. In addition to that, the sense of the lexical words is restricted by the translators. Some words have been translated as their referent in the real world without considering their sense in the language system.(ibid).

\section{METHODOLOGY}

This part deals with the methodology used in this study. It deals first with the choice of translations to be investigated. The second section contains a full description of the subjects. The instruments are described in the section of the research procedures. Moreover, the section will explain how the collected data would be statistically analyzed.

\section{Choice of Translations}

The present study uses five translations of the Qur'an.

- The first translation is The Holy Qur'an: translation and commentary by Abdullah Yusuf Ali (1934).

- The second translation, The meaning of the Glorious Koran, by Pickthall (1930), who is a convert to Islam.

- The third translation is The Koran Commonly Called Alkoran of Mohammed by George Sale (1734).

- Shakir's translation The Qur'an Arabic and English (1981) is the fourth translation.

- The last translation is Qaribullah's The Meaning of the Glorious Koran (2001) in collaboration with Sheik Ahmed Darwich from Al-Azhar.

The choice of the five translations is based on the cultural background of the translators since it has been assumed that the cultural background may affect translation of the Qur'an into English.

Yusuf Ali is an Indian Muslim, who was fluent in Arabic though his background, although he was not an Arab. He 
translated the Qur'an representing Sunna ${ }^{(1)}$ principles. Sale and Pickthall share the same origin and background as they were both British; whereas Sale was Christian and was accused of being anti-Islam (see Mohammed 2005), Pickthall converted to Islam. Habib and Qaribullah are Arab Muslims who represent different doctrines. Habib represents Shi'a ${ }^{(2)}$ and Qaribullah represents $\operatorname{Sufi}^{(3)}$.

In order to compare and contrast these five English translations, (2) words are chosen. The words are chosen because they are key words that refer to the most important values in Muslim Heritage. The words chosen are polysemous nouns that describe positive entities such as virtues and humanity. For example, the word virtue represents a concept that plays an important role in building and maintaining social relations in a broad sense, and ties between individuals especially family members. The (2) chosen words correspond to (18) equivalent words in English as each word in Arabic has got between two to five alternatives in the English translations.

The researchers first intended to use two corpora, English and Arabic, to gain insight into the concepts described by the words selected for this study, and do a collocation analysis. However, while a good English corpus is readily available (e.g. the British National Corpus), there is no such corpus for Arabic. Another problem in relation to Arabic was that corpora of modern Arabic are available, but they seem to be commonly used only in newspaper archives as in Al-Hayat the daily newspaper. What does not seem to be available is a corpus that balances different genres, like the British National Corpus (BNC).

The Qur'an is revealed in Classical Arabic. Thus, the collocation found in the corpus which consists of modern Arabic would not necessarily be relevant to the language of the Qur'an. For these reasons, we decided not to use corpora.

\section{Subjects}

The sample of the study is a group of Muslim Arabs of different ages, with different educational qualifications and different occupations, who speak Arabic as their first language and English as their second language. The sample of subjects was drawn from Arab students studying in British universities as Manchester and Salford as well as the Arab community in the town of Lancaster. All the subjects were residents of the UK, and have been living there for one 1 year, up to 35 years. (Table 3.1) shows the distribution of population according to age group and sex of the respondents to the questionnaires.

\section{Instruments}

The instrument used is the questionnaire designed for the purpose of the study. It was intended to elicit participants' opinions about the appropriateness of the given translations, as found across the five Qur'an translations in question.

The questionnaire consists of (18) items. Each item asks about the appropriateness of (3 to 5) possible options of translations of a single lexical item, selected from the different translations of the Qur'an.

The words were chosen according to differences in meanings in different context. Each lexical item is followed
Table 3.1. Distribution of subjects according to age and sex

\begin{tabular}{lccc}
\hline Age group & \multicolumn{2}{c}{ Sex } & Total \\
\cline { 2 - 3 } & Female & Male & \\
\hline Less than 30 & 14 & 11 & 25 \\
31 to 40 & 7 & 23 & 30 \\
41 to 50 & 3 & 15 & 18 \\
51 or more & 1 & 2 & 3 \\
Total & 25 & 51 & 76 \\
\hline
\end{tabular}

by five options. However, the options are sometimes fewer than five options, because on a number of occasions some translations choose the same English words. For example, the word 'assalam' is given the same equivalent 'salutation' by Yusuf Ali, Qaribullah and Shakir. Thus, the five translations are reduced to three (see 3 below). Each word is given in the verse in which it is used in the translations. Here are some examples taken from the questionnaire:

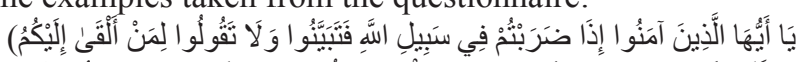

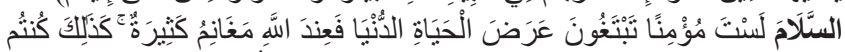

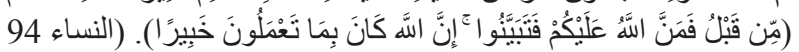

Three different translations of the word (السلام:Assalam) : 3 options in the questionnaire

\begin{tabular}{|c|c|c|c|c|c|}
\hline Meaning & $\begin{array}{l}1 \\
\text { Completely } \\
\text { appropriate }\end{array}$ & 2 & 3 & 4 & $\begin{array}{l}5 \text { Completely } \\
\text { inappropriate }\end{array}$ \\
\hline $\begin{array}{l}\text { 1- Who } \\
\text { offers you } \\
\text { salutation }\end{array}$ & & & & & \\
\hline $\begin{array}{l}\text { 2- Who } \\
\text { offereth } \\
\text { you peace }\end{array}$ & & & & & \\
\hline $\begin{array}{l}\text { 3- Who } \\
\text { saluteth you }\end{array}$ & & & & & \\
\hline
\end{tabular}

We have utilized the questionnaire as instrument with a Likert 5-points scale. Each alternative is assigned a numerical value ranging from 5 for 'completely appropriate' to 1 for 'completely inappropriate' with 2, 3, and 4 intermediate between the two extremes and left without explicit descriptors. These points were left blank in order to encourage subjects to treat them as equidistant from each other. The advantage of this is that the Likert scale is not necessarily an ordinal scale, as is usually the case, but may be interpreted as an interval scale, which makes it possible to do more powerful statistical tests on the results. Cramer (1994) states that by using a Likert scale "with interval level measurement, the intervals between numbers denote equal amounts of the attribute being assessed".

The first four items of the questionnaire are about the word 'السلام' (assalam) as used in different contexts and different translations. It has different senses which are; 'salutation' twice, 'safety', 'paradise', and 'peace'. Peace also is one of the names of Allah Almighty. The following four items are about the word الفضل 'alfadl', which is a polyse- 
mous word having the meaning of 'grace', 'bounty', 'generosity', 'wealth', and 'favour'.

A pilot study had been carried out to test the validity of the questionnaire using earlier versions of the questionnaires which were distributed to a sample drawn from the target group. The sample consisted of 20 participants, 15 of them were students at Lancaster University and 5 participants from the town of Lancaster, to comment on the 18 questions which constituted the questionnaire (Arabic-English questionnaire). In the light of the comments received some modifications were made as a result of questions that emerged in the pilot study. The participants were asked to write their own translation of the items in the questionnaire if they wished. Ten participants have given their own translation of some words.

\section{Procedures}

We have distributed 100 copies but only 76 were returned completed, 39 of the Arabic version and 37 of the English version were filled in and returned. Since the study is quantitative rather than being qualitative, the Statistical Package for Social Science (SPSS, version 16.0) was used to analyze the data. Means comparison was carried out for the first questionnaire.

\section{Summary}

To sum up, this section dealt with the description of the method followed in conducting the study. The subjects and the instruments were described and the procedures followed were stated. The choice of the words to be investigated was made and five translations following each word have been made. The questionnaire was used to measure the appropriateness of the five translations for Arab Muslims who speak English as their second language. The English version was administered to English native speakers. It intended to discover differences in two speakers' frame knowledge. Descriptive statistical analysis was used to analyze the collected data.

\section{DATA ANALYSIS, RESULTS AND DISCISSION}

This chapter deals with the data analysis. It includes the analysis of the data collected by the questionnaire (Arabic-English), for Muslims, which consisted of 18 items. The frequencies are presented and the mean scores are rank-ordered and the chi square test results are included. The analysis of the data is based on Statistical Package for Social Sciences.

\section{Arabic-English Questionnaire}

This section includes the analysis of the Arabic-English questionnaire which deals with the translation of the words, 'asslam', 'alfadl', in different contexts (verses). The participant were asked to choose what they think is the most appropriate translation.

Firstly, the different translations of the word 'assalam' which is translated 'who offers you salutation', ' who offereth you peace' and 'who saluteth you' are analyzed in the Tables 4.1A, 4.1B, 4.1C below.
Table 4.1A above shows the translation given by Yusuf Ali, 'who offers you salutation'. $28.9 \%$ of the participants think it is completely appropriate while $13.2 \%$ of them see it as completely inappropriate.

Table 4.1B shows that the translation given by Pickthall, Shakir and Qaribullah, 'who offerth you peace'. $48.75 \%$ of the participants think that it is completely appropriate while $9.2 \%$ of them see it as completely inappropriate.

Table $4.1 \mathrm{C}$ shows the translation given by Sale, 'who salutheth you'. $18.4 \%$ of the participants think it is completely appropriate and $14.5 \%$ of them see it as completely inappropriate.

Table 4.1A. Frequencies and percentages of Yusuf Ali, Shakir and Qaribullah's translations for the first meaning of the word 'assalam'

\begin{tabular}{|c|c|c|}
\hline & & \\
\hline Who off & u salutation & \\
\hline Scale & Frequency & Percent \\
\hline Completely inappropriate & 10 & 13.2 \\
\hline 2 & 21 & 27.6 \\
\hline 3 & 16 & 21.1 \\
\hline 4 & 7 & 9.2 \\
\hline Completely appropriate & 22 & 28.9 \\
\hline Total & 76 & 100.0 \\
\hline
\end{tabular}

Table 4.1B. Frequencies and percentages of Pickthall's translation for the first meaning of the word 'assalam'

\begin{tabular}{lcc}
\hline \multicolumn{3}{c}{ Item } \\
\hline Wcale & Who offereth you peace \\
\hline Completely appropriate & 7 & Percent \\
2 & 18 & 9.2 \\
3 & 9 & 23.7 \\
4 & 5 & 11.8 \\
Completely inappropriate & 37 & 6.6 \\
Total & 76 & 48.7 \\
\hline
\end{tabular}

Table 4.1C. Frequencies and percentages of Sale's translation for the first meaning of the word 'assalam'

\begin{tabular}{lcc}
\hline \multicolumn{3}{c}{ Item } \\
\hline Whale & Frequency & Percent \\
\hline Completely inappropriate & 14 & 18.4 \\
2 & 18 & 23.7 \\
3 & 19 & 25.0 \\
4 & 14 & 18.4 \\
Completely appropriate & 11 & 14.5 \\
Total & 76 & 100.0 \\
\hline
\end{tabular}


Table 4.2 above shows the mean scores, standard deviations and the rank ordering of the different translations of the first meaning of the word 'assalam'. The lowest and highest mean scores are compared and rank ordered. The chi square test is also performed to show the relation between the Highest and lowest mean scores of translations of the word ' $a s$ salam' in its first context.

The translation which received the lowest mean score was Sale's translation $(\mathrm{M}=2.87)$, while Pickthall's translation received the highest mean score of $(\mathrm{M}=3.62)$.

The next lowest mean score was assigned to Yusuf Ali, Shakir and Qaribullah's translation. Therefore the difference between the appropriateness of these translations is highly significant. In other words the translation by Yusuf Ali, Shakir and Qaribullah is clearly judged to be more appropriate than Sale's.

From the results shown in (Table 4.2) it is clear that the translations of Pickthall is more appropriate than Sale's followed by Yusuf Ali, Shakir and Qaribullah's translation. Sale's translation of the first meaning of the word 'al-salam' is the least appropriate.

The word 'assalam' in its second context is translated as, 'ways of peace and safety' by Yusuf Ali, 'ways of safety', by Shakir and, 'paths of peace' by Pickthall, Qaribullah and Sale as shown in Tables 4.3A, 4.3B and 4.3C below.

The tables above show the different translations of the second meaning of the word 'assalam'.

Table $4.3 \mathrm{~A}$ shows the translation given by Yusuf Ali 'ways of peace and safety'. 46.1\% of the respondents say it is completely appropriate whereas $3.9 \%$ say it is completely inappropriate. Table $4.3 \mathrm{~B}$ shows the translation given by Pickthall, Qaribullah and Sale, 'paths of peace'.25\% of the respondents rated it as completely appropriate and $10.5 \%$ of them rate it as completely inappropriate. Table $4.3 \mathrm{C}$ shows the translation given by Shakir, 'ways of safety'. $14.5 \%$ of the respondents say it is completely appropriate and $13.2 \%$ of them say it is completely inappropriate.

Table 4.4 above shows the mean scores, standard deviations and the rank order of the translations of the second meaning of the word 'assalam'. The mean scores assigned to each are ranked ordered and compared and then a chi square test was performed to assess the relative appropriacy of the various translations. Shakir's translation was assigned the lowest mean score $(\mathrm{M}=2.83)$ while the highest mean score was received by Yusuf Ali's translation $(M=3.70)$. The difference between Yusuf Ali's translation and Shakir's translation is not significant. The second lowest mean score was received by Pickthall, Qaribullah and Sale's translations $(\mathrm{M}=3.22)$.This result indicates a significant difference between the translations of Pickthall, Qaribulla, Sale on one hand and the translation of Shakir on the other hand. The word 'assalam' in its third context translated as 'home of peace', by Yusuf Ali. 'abode of peace', by Pickthall, Shakir and Qaribullah and 'dwelling of peace', by Sale.

As to Yusuf Ali's translation, 'home of peace'.42.1\% of the respondents think that it is completely appropriate while $10.5 \%$ of them think it is completely inappropriate (Table 4.5A). 'Abode of peace', given by Pickthall, Sha-
Table 4.2. Mean scores, standard deviations and rank ordering for all the translations of the first meaning of the word 'assalam'

\begin{tabular}{lcccc}
\hline Translations & N & Mean & $\begin{array}{c}\text { Standard } \\
\text { deviation }\end{array}$ & Rank order \\
\hline Yusuf Ali & 76 & 3.1316 & 1.43613 & 2 \\
Pickthall & 76 & 3.6184 & 1.50525 & 1 \\
Shakir & 76 & 3.1316 & 1.43613 & 2 \\
Qaribullah & 76 & 3.1316 & 1.43613 & 2 \\
Sale & 76 & 2.8684 & 1.32002 & 3 \\
Total & 76 & & & \\
\hline
\end{tabular}

Table 4.3A. Frequencies and percentages of Yusuf Ali's translation for the second meaning of the word 'assalam'

\begin{tabular}{lcc}
\hline \multicolumn{3}{c}{ Item } \\
\hline Ways of peace and safety \\
\hline Scale & Frequency & Percent \\
\hline Completely inappropriate & 3 & 3.9 \\
2 & 17 & 22.4 \\
3 & 15 & 19.7 \\
4 & 6 & 7.9 \\
Completely appropriate & 35 & 46.1 \\
Total & 76 & 100.0 \\
\hline
\end{tabular}

Table 4.3B. Frequencies and percentages of Pickthall, Qaribullah and Sale's translations for the second meaning of the word 'assalam'

\begin{tabular}{lcc}
\hline \multicolumn{3}{c}{ Item } \\
\hline Paths of peace \\
\hline Scale & Frequency & Percent \\
\hline Completely inappropriate & 8 & 10.5 \\
2 & 19 & 25.0 \\
3 & 16 & 21.1 \\
4 & 14 & 18.4 \\
Completely appropriate & 19 & 25.0 \\
Total & 76 & 100.0 \\
\hline
\end{tabular}

Table 4.3C. Frequencies and percentages of Shakir's translation for the second meaning of the word 'assalam'

\begin{tabular}{lcc}
\hline \multicolumn{3}{c}{ Item } \\
\hline \multicolumn{3}{c}{ Ways of safety } \\
\hline Scale & Frequency & Percent \\
\hline Completely inappropriate & 11 & 14.5 \\
2 & 23 & 30.3 \\
3 & 20 & 26.3 \\
4 & 12 & 15.8 \\
Completely appropriate & 10 & 13.2 \\
Total & 76 & 100.0 \\
\hline
\end{tabular}


kir and Qaribullah was seen as completely appropriate by $26.3 \%$ of he respondents and as completely inappropriate by $13.2 \%$ of the respondents (Table $4.5 \mathrm{~B}$ ) The respondents. Sale's translation 'dwelling of peace' was seen as completely inappropriate by $28.9 \%$ of the participants while $22.4 \%$ of them see it as completely appropriate.

Table 4.6 above shows the mean scores, standard deviations and the ranks ordering of the third meaning of the word 'assalam'. The mean scores assigned to each are ranked ordered, compared and then a chi square test was conducted to assess the relative appropriacy of the various translations. The lowest mean score was assigned to the translation of Sale $(\mathrm{M}=2.87)$ while the highest mean score was assigned to Yusuf Ali's translation $(\mathrm{M}=3.51)$. The difference between the two translations is significant. This leads to the conclusion that the subjects have preference to Yusuf Ali's translation than to Sale's. Pickthall, Shakir and Qaribullah's translations were assigned the same mean score $(M=3.18)$. The result shows that there is a very high significant difference between Pickthall, Shakir, Qaribullah's translations on one hand and Sale's on the other hand. Thus, they have been judged by the respondents as more appropriate translations than Sale's.

Accordingly, the rank ordering of the five translations of the word 'assalam' in this context is, Yusuf Ali's translation ranked first as the most appropriate translation. The second most appropriate translation were Shakir's Pickthall and Qaribullah's followed by Sale's. It was rated as the least appropriate translation.

In the last context of the word 'assalam' is translated as, 'the source of peace and perfection', 'peace', 'giver of peace', and 'the peace'.

Table 4.4. Mean scores, standard deviations and the rank ordering of all translations of the second meaning of the word 'assalam'

\begin{tabular}{lcccc}
\hline Translations & N & Mean & $\begin{array}{c}\text { Standard } \\
\text { deviation }\end{array}$ & Rank order \\
\hline Yusuf Ali & 76 & 3.6974 & 1.35666 & 1 \\
Pickthall & 76 & 3.2237 & 1.35252 & 2 \\
Shakir & 76 & 2.8289 & 1.24781 & 3 \\
Qaribullah & 76 & 3.2237 & 1.35252 & 2 \\
Sale & 76 & 3.2237 & 1.35252 & 2 \\
Total & 76 & & & \\
\hline
\end{tabular}

Table 4.5A. Frequencies and percentages of Yusuf Ali's translation for the third meaning of the word 'assalam'

\begin{tabular}{lcc}
\hline \multicolumn{3}{c}{ Item } \\
\hline Home of peace \\
\hline Completely inappropriate & Frequency & Percent \\
2 & 8 & 10.5 \\
3 & 14 & 18.4 \\
4 & 17 & 22.4 \\
Completely appropriate & 5 & 6.6 \\
Total & 32 & 42.1 \\
\hline
\end{tabular}

Tables 4.7A, 4.7B, 4.7C, 4.7D above show the translations of the fourth and last meaning of the word 'assalam'. Table 4.7A shows the translation given by Yusuf Ali, 'the source of peace and perfection'.44.7\% of the respondents think that it is completely appropriate and only $3.9 \%$ of them think it is completely inappropriate. Table 4.7B shows the translation given by Pickthall, 'peace'. $19.7 \%$ of the respondents think that it is completely appropriate while $17.1 \%$ of them think it is completely inappropriate.

Table $4.7 \mathrm{C}$ show the translation given by Shakir and Sale, 'the Giver of peace'. 18.4\% of the respondents think it is completely appropriate and $11.8 \%$ of them see it as completely inappropriate. Table $4.7 \mathrm{D}$ shows the translation of Qaribullah, 'the peace'. $30.3 \%$ of the respondents think it is

Table 4.5B. Frequencies and percentages of Pickthall, Shakir and Qaribullah's translation for the third meaning of the word 'assalam'

\begin{tabular}{lcc}
\hline \multicolumn{3}{c}{ Item } \\
\hline \multicolumn{3}{c}{ Abode of peace } \\
\hline Scale & Frequency & Percent \\
\hline Completely inappropriate & 10 & 13.2 \\
2 & 16 & 21.1 \\
3 & 20 & 26.3 \\
4 & 10 & 13.2 \\
Completely appropriate & 20 & 26.3 \\
Total & 76 & 100.0 \\
\hline
\end{tabular}

Table 4.5C. Frequencies and percentages of Sale's translation for the third meaning of the word 'assalam'

\begin{tabular}{lcc}
\hline \multicolumn{3}{c}{ Item } \\
\hline Dwelling of peace \\
\hline Completely inappropriate & Frequency & Percent \\
2 & 22 & 28.9 \\
3 & 11 & 14.5 \\
4 & 15 & 19.7 \\
Completely appropriate & 11 & 14.5 \\
Total & 17 & 22.4 \\
\hline
\end{tabular}

Table 4.6. Mean scores, standard deviations and the rank ordering of the translations for the third meaning of the word 'assalam'

\begin{tabular}{lcccc}
\hline Translations & N & Mean & $\begin{array}{c}\text { Standard } \\
\text { deviation }\end{array}$ & Rank order \\
\hline Yusuf Ali & 76 & 3.5132 & 1.45596 & 1 \\
Pickthall & 76 & 3.1842 & 1.38285 & 2 \\
Shakir & 76 & 3.1842 & 1.38285 & 2 \\
Qaribullah & 76 & 3.1842 & 1.38285 & 2 \\
Sale & 76 & 2.8684 & 1.53486 & 3 \\
Total & 76 & & & \\
\hline
\end{tabular}


Table 4.7A. Frequencies and percentages of Yusuf Ali's translation for the fourth meaning of the word 'assalam'

\begin{tabular}{lcc}
\hline \multicolumn{3}{c}{ Item } \\
\hline \multicolumn{3}{c}{ The source of peace and perfection } \\
\hline Scale & Frequency & Percent \\
\hline Completely inappropriate & 3 & 3.9 \\
2 & 23 & 30.3 \\
3 & 12 & 15.8 \\
4 & 4 & 5.3 \\
Completely appropriate & 34 & 44.7 \\
Total & 76 & 100.0 \\
\hline
\end{tabular}

Table 4.7B. Frequencies and percentages of Pickthall's translation for the fourth meaning of the word 'assalam'

\begin{tabular}{lcc}
\hline \multicolumn{3}{c}{ Item } \\
\hline Peace \\
\hline Scale & Frequency & Percent \\
\hline Completely inappropriate & 13 & 17.1 \\
2 & 22 & 28.9 \\
3 & 16 & 21.1 \\
4 & 10 & 13.2 \\
Completely appropriate & 15 & 19.7 \\
Total & 76 & 100.0 \\
\hline
\end{tabular}

Table 4.7C. Frequencies and percentages of Shakir and Sale's translations for the fourth meaning of the word 'assalam'

\begin{tabular}{lcc}
\hline \multicolumn{3}{c}{ Item } \\
\hline \multicolumn{3}{c}{ The giver of peace } \\
\hline Scale & Frequency & Percent \\
\hline Completely inappropriate & 9 & 11.8 \\
2 & 22 & 28.9 \\
3 & 26 & 34.2 \\
4 & 5 & 6.6 \\
Completely appropriate & 14 & 18.4 \\
Total & 76 & 100.0 \\
\hline
\end{tabular}

completely appropriate while $18.4 \%$ of them see it as completely inappropriate.

Table 4.8 above shows the mean scores, standard deviations and the rank order of the translations of the last meaning of the word 'assalam'. The mean scores were compared and ranked ordered according to the lowest and highest mean scores. The lowest mean score was received by the translation of Pickthall $(\mathrm{M}=2.89)$ and the highest by the translation of Yusuf Ali $(\mathrm{M}=3.57)$. The difference between the two translations is significant. That is to say that the translation of Yusuf Ali was seen better in terms of appropriateness than the translation of Pickthall.

The second lowest mean score was assigned to Shakir, Qaribullah and sale's translation $(\mathrm{M}=2.91)$. There is no significant difference between the translation of Shakir,
Table 4.7D. Frequencies and percentages of Qaribullah's translation for the fourth meaning of the word 'assalam'

\begin{tabular}{lcc}
\hline \multicolumn{3}{c}{ Item } \\
\hline \multicolumn{3}{c}{ The peace } \\
\hline Scale & Frequency & Percent \\
\hline Completely inappropriate & 14 & 18.4 \\
2 & 19 & 25.0 \\
3 & 13 & 17.1 \\
4 & 7 & 9.2 \\
Completely appropriate & 23 & 30.3 \\
Total & 76 & 100.0 \\
\hline
\end{tabular}

Table 4.8. Mean scores, standard deviations and rank ordering for all translations for the fourth meaning of the word 'assalam'

\begin{tabular}{lcccc}
\hline Translations & N & Mean & $\begin{array}{c}\text { Standard } \\
\text { deviation }\end{array}$ & Rank order \\
\hline Yusuf Ali & 76 & 3.5658 & 1.41737 & 1 \\
Pickthall & 76 & 2.8947 & 1.38158 & 4 \\
Shakir & 76 & 2.9079 & 1.25621 & 3 \\
Qaribullah & 76 & 3.0789 & 1.52108 & 2 \\
Sale & 76 & 2.9079 & 1.25621 & 3 \\
Total & 76 & & & \\
\hline
\end{tabular}

Qaribullah, Sale on one hand and Pickthall's on the other hand.

The next highest mean score was received by the translation of Qaribullah $(\mathrm{m}=34.95)$. This result indicates a significant difference between the two translations. That means the translation of Qaribullah is considered to be more appropriate than Pickthall's translation.

Thus, the best translation in terms of appropriateness is the translation of Yusuf Ali followed by Qaribullah, Shakir and sale's translation and the least appropriate one is Shakir's.

Secondly: The second word is 'alfadl الفضل' which has got four different meanings in different contexts. For the first meaning, it is translated as, 'liberality', "giving of free gift', 'kindness and generosity'.

Table 4.9A, 4.9B, 4.9C and 4.9D above show the translations of the first meaning of the word 'alfadl'. Table 4.9A shows the translation given by Yusuf Ali and Sale, 'liberality'.27.6\% of the respondents think it is completely inappropriate and $22.4 \%$ of them see it as completely appropriate. Table 4.9B shows the translation given by Pickthall, 'kindness' $34.2 \%$ of the participants rate it as completely appropriate while $10.5 \%$ of them see it as completely inappropriate. Table 4.9C shows the translation given by Shakir, 'giving free gift'.27.6\% of the participants think that it is completely inappropriate and $11.8 \%$ of them see it as completely appropriate. Table 4.9D shows the translation given by Qaribullah, 'generosity'. 27.6\% of the participants think it is completely appropriate and only $5.3 \%$ of them see it as completely inappropriate.

Table 4.10 above shows the mean scores, standard deviations and rank ordering of the given translation of the 
Table 4.9A. Frequencies and percentages of Yusuf Ali and Sale's translation for the first meaning of the word 'alfadl'

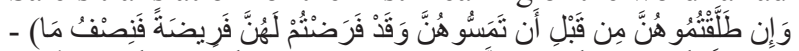

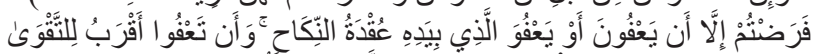

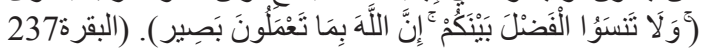

\begin{tabular}{lcc}
\hline \multicolumn{3}{c}{ Item } \\
\hline Siberality \\
\hline Completely inappropriate & Frequency & Percent \\
2 & 21 & 27.6 \\
3 & 13 & 17.1 \\
4 & 13 & 17.1 \\
Completely appropriate & 12 & 15.8 \\
Total & 17 & 22.4 \\
\hline
\end{tabular}

Table 4.9B. Frequencies and percentages of Pickthall's translation for the first meaning of the word 'alfadl'

\begin{tabular}{lcc}
\hline \multicolumn{3}{c}{ Item } \\
\hline \multicolumn{3}{c}{ Kindness } \\
\hline Scale & Frequency & Percent \\
\hline Completely inappropriate & 8 & 10.5 \\
2 & 25 & 32.9 \\
3 & 13 & 17.1 \\
4 & 4 & 5.3 \\
Completely appropriate & 26 & 34.2 \\
Total & 76 & 100.0 \\
\hline
\end{tabular}

Table 4.9C. Frequencies and percentages of Shakir's translation for the first meaning of the word 'alfadl'

\begin{tabular}{lcc}
\hline \multicolumn{3}{c}{ Item } \\
\hline \multicolumn{3}{c}{ Giving free gift } \\
\hline Scale & Frequency & Percent \\
\hline Completely inappropriate & 21 & 27.6 \\
2 & 12 & 15.8 \\
3 & 13 & 17.1 \\
4 & 21 & 27.6 \\
Completely appropriate & 9 & 11.8 \\
Total & 76 & 100.0 \\
\hline
\end{tabular}

Table 4.9D. Frequencies and percentages of Qaribullah's translation for the first meaning of the word 'alfadl'

\begin{tabular}{lcc}
\hline \multicolumn{3}{c}{ Item } \\
\hline Generosity \\
\hline Completely inappropriate & Frequency & Percent \\
2 & 4 & 5.3 \\
3 & 15 & 19.7 \\
4 & 25 & 32.9 \\
Completely appropriate & 11 & 14.5 \\
Total & 21 & 27.6 \\
\hline
\end{tabular}

Table 4.10. Mean scores, standard deviations and the rank ordering for all translations of the first meaning of the word 'alfadl'

\begin{tabular}{lcccc}
\hline Translations & N & Mean & $\begin{array}{c}\text { Standard } \\
\text { deviation }\end{array}$ & $\begin{array}{c}\text { Rank } \\
\text { order }\end{array}$ \\
\hline Yusuf Ali & 76 & 2.8816 & 1.53160 & 3 \\
Pickthall & 76 & 3.1974 & 1.46987 & 2 \\
Habib & 76 & 2.8026 & 1.41440 & 4 \\
Qaribullah & 76 & 3.3947 & 1.23374 & 1 \\
Sale & 76 & 2.8816 & 1.53160 & 3 \\
Valid N (listwise) & 76 & & & \\
\hline
\end{tabular}

first meaning of the word 'alfadl'. The lowest mean scores are compared and rank ordered. The lowest mean score of the word 'alfadl', was scored by the translation of Shakir $(\mathrm{M}=2.80)$ while the highest was received by Qaribullah's $(\mathrm{M}=3.39)$. The difference between the two translations is not significant which indicates that the translation of Qaribullah is judged to be about equally appropriate as the translation of Shakir.The next lowest mean score was scored by the translation of Yusuf and Sale $(\mathrm{M}=2.88)$. Accordingly there is no significant differences between the translation of Yusuf and Sale's translation on one hand and on the other hand Qaribullah's.

The third lowest mean score was assigned to Pickthall's translation. As a result the relation between the two translations is not significant.In other words the translation of Sale is better than Shakir's, although Shakir has an Arabic background while Sale is British with different native language and culture. The result shows that the translation of Sale is the best translation followed by the translation of Yusuf Ali while the translations of Pickthall, Qaribullah and Shakir are as roughly equally appropriate by our participants.

The second meaning of the word 'alfadl' is translated as, 'all bounties', 'the bounty' and 'excellence'.

The Tables (4.11A, 4.11B, 4.11C, 4.11D and (4.11E) above show the different translations given for the second meaning of the word 'alfadl'. Table 4.11A shows the translation given by Yusuf Ali, 'all bounties'. 36.8\% of the participants say it is completely appropriate while only $2.6 \%$ of them see it as completely inappropriate. Table $4.11 \mathrm{~B}$ shows the translation given by Pickthall, 'the bounty'.25\% of the participants rate it as completely appropriate and only $7.9 \%$ of them rate it as completely appropriate. Table $4.11 \mathrm{C}$ shows the translation given by Shakir, 'grace'.26.3\% of the respondents say it is completely appropriate, whereas $11.8 \%$ say it is completely inappropriate. Table $4.11 \mathrm{D}$ shows the translation given by Qaribullah, 'bounty'.30.3\% of the participants see it as completely appropriate while $5.3 \%$ of them see it as completely inappropriate. Table $5.11 \mathrm{E}$ shows the translation given by Sale, 'excellence'.39.5\% of the respondents think it is completely inappropriate and only $6.6 \%$ of them think it is completely appropriate.

Table 4.12 above shows the means scores, standard deviation and the ranks ordering of the second meaning of the word 'alfadl'. The mean scores assigned to each are ranked 
Table 4.11A. Frequencies and percentages of Yusuf Ali's translation for the second meaning of the word 'alfadl'

\begin{tabular}{lcc}
\hline \multicolumn{3}{c}{ Item } \\
\hline \multicolumn{3}{c}{ All bounties } \\
\hline Scale & Frequency & Percent \\
\hline Completely inappropriate & 2 & 2.6 \\
2 & 20 & 26.3 \\
3 & 20 & 26.3 \\
4 & 6 & 7.9 \\
Completely appropriate & 28 & 36.8 \\
Total & 76 & 100.0 \\
\hline
\end{tabular}

Table 4.11B. Frequencies and percentages of Pickthall's translation for the second meaning of the word 'alfadl'

\begin{tabular}{lcc}
\hline \multicolumn{3}{c}{ Item } \\
\hline \multicolumn{3}{c}{ The bounty } \\
\hline Scale & Frequency & Percent \\
\hline Completely inappropriate & 6 & 7.9 \\
2 & 28 & 36.8 \\
3 & 14 & 18.4 \\
4 & 9 & 11.8 \\
Completely appropriate & 19 & 25.0 \\
Total & 76 & 100.0 \\
\hline
\end{tabular}

Table 4.11C. Frequencies and percentages of Shakir's translation for the second meaning of the word 'alfadl'

\begin{tabular}{lcc}
\hline \multicolumn{3}{c}{ Item } \\
\hline Grace \\
\hline Scale & Frequency & Percent \\
\hline Completely inappropriate & 9 & 11.8 \\
2 & 19 & 25.0 \\
3 & 18 & 23.7 \\
4 & 10 & 13.2 \\
Completely appropriate & 20 & 26.3 \\
Total & 76 & 100.0 \\
\hline
\end{tabular}

Table 4.11D. Frequencies and percentages of Qaribulah's translation for the second meaning of the word 'alfadl'

\begin{tabular}{lcc}
\hline \multicolumn{3}{c}{ Item } \\
\hline Bounty \\
\hline Scale & Frequency & Percent \\
\hline Completely inappropriate & 4 & 5.3 \\
2 & 23 & 30.3 \\
3 & 17 & 22.4 \\
4 & 9 & 11.8 \\
Completely appropriate & 23 & 30.3 \\
Total & 76 & 100.0 \\
\hline
\end{tabular}

Table 4.11E. Frequencies and percentages of Sale's translation for the second meaning of the word 'alfadl'

\begin{tabular}{lcc}
\hline \multicolumn{3}{c}{ Item } \\
\hline Excellence \\
\hline Completely inappropriate & Frequency & Percent \\
2 & 30 & 39.5 \\
3 & 10 & 13.2 \\
4 & 15 & 19.7 \\
Completely appropriate & 16 & 21.1 \\
Total & 5 & 6.6 \\
\hline
\end{tabular}

Table 4.12. Mean scores, standard deviations and rank ordering for all the translations of the second meaning of the word 'alfadl'

\begin{tabular}{lcccc}
\hline Translations & N & Mean & $\begin{array}{c}\text { Standard } \\
\text { deviation }\end{array}$ & $\begin{array}{c}\text { Rank } \\
\text { order }\end{array}$ \\
\hline Yusuf Ali & 76 & 3.5000 & 1.30128 & 5 \\
Pickthall & 76 & 3.0921 & 1.34836 & 2 \\
Shakir & 76 & 3.1711 & 1.37974 & 3 \\
Qaribullah & 76 & 3.3158 & 1.32876 & 4 \\
Sale & 76 & 2.4211 & 1.36883 & 1 \\
Valid N (listwise) & 76 & & & \\
\hline
\end{tabular}

ordered, compared and then a chi square test was performed to assess the relative appropriacy of the various translations. The lowest mean score between the five translations was received by Sale's translation $(\mathrm{M}=2.42)$ and the highest was assigned to Yusuf Ali's $(M=3.50)$. There is no significant difference between the translation of Yusuf Ali and the translation of Sale and this lack of significance between the two translations is probably due to some outliers in the participants' responses.

The translation of Pickthall scored the next lowest mean score $(\mathrm{M}=3.09)$. The difference between the two translations is not significant. The translation of Shakir received the lowest mean score after Pickthall's ( $M=3.17)$. There is no significant difference between the two translations. The last lowest mean score among the five translations was assigned to Qaribullah's translation $(\mathrm{M}=3.31)$. The values indicate no significant difference between the translation of Yusuf Ali and Qaribullah's. Therefore, all the translations are perceived as equally appropriate by the participants. The third meaning of the word 'alfadl' is translated here as, 'who possess grace and amplitude of means', ' who possess dignity and ease', 'who possess bounty and plenty swear', 'who possess abundance of wealth' and 'who possess grace and abundance'.

Tables (4.13A, 4.13B, 4.13C, 4.13D and 4.13E) above show the different translations of third meaning of the word 'alfadl'. Table 4.13A shows the translation given by Yusuf Ali, 'with who are endued grace and amplitude of means'. $35.5 \%$ of the participants think it is completely appropri- 
Table 4.13A. Frequencies and percentages of Yusuf Ali's translation for the third meaning of the word 'alfadl'

\begin{tabular}{lcc}
\hline \multicolumn{3}{c}{ Item } \\
\hline \multicolumn{3}{c}{ Who are endued grace and amplitude of means } \\
\hline Scale & Frequency & Percent \\
\hline Completely inappropriate & 7 & 9.2 \\
2 & 15 & 19.7 \\
3 & 16 & 21.1 \\
4 & 11 & 14.5 \\
Completely appropriate & 27 & 35.5 \\
Total & 76 & 100.0 \\
\hline
\end{tabular}

Table 4.13B. Frequencies and percentages of Pickthall's translation for the third meaning of the word 'alfadl'

\begin{tabular}{lcc}
\hline \multicolumn{3}{c}{ Item } \\
\hline \multicolumn{3}{c}{ Who possess dignity and easy } \\
\hline Scale & Frequency & Percent \\
\hline Completely inappropriate & 19 & 25.0 \\
2 & 14 & 18.4 \\
3 & 24 & 31.6 \\
4 & 12 & 15.8 \\
Completely appropriate & 7 & 9.2 \\
Total & 76 & 100.0 \\
\hline
\end{tabular}

Table 4.13C. Frequencies and percentages of Shakir's translation for the third meaning of the word 'alfadl'

\begin{tabular}{lcc}
\hline \multicolumn{3}{c}{ Item } \\
\hline Wcale & Frequency & Percent \\
\hline Completely inappropriate & 9 & 11.8 \\
2 & 16 & 21.1 \\
3 & 13 & 17.1 \\
4 & 19 & 25.0 \\
Completely appropriate & 19 & 25.0 \\
Total & 76 & 100.0 \\
\hline
\end{tabular}

Table 4.13D. Frequencies and percentages of Qaribullah's translation of the third meaning of the word 'alfadl'

\begin{tabular}{lcc}
\hline \multicolumn{3}{c}{ Item } \\
\hline Who possess dignity and plenty swear \\
\hline Scale & Frequency & Percent \\
\hline Completely inappropriate & 14 & 18.4 \\
2 & 15 & 19.7 \\
3 & 22 & 28.9 \\
4 & 17 & 22.4 \\
Completely appropriate & 8 & 10.5 \\
Total & 76 & 100.0 \\
\hline
\end{tabular}

Table 4.13E. Frequencies and percentages of Sale's translation of the third meaning of the word 'alfadl'

\begin{tabular}{lcc}
\hline \multicolumn{3}{c}{ Item } \\
\hline Wcale & Fho possess a abundance of wealth \\
\hline Completely inappropriate & 4 & Percent \\
2 & 20 & 5.3 \\
3 & 15 & 26.3 \\
4 & 12 & 19.7 \\
Completely appropriate & 25 & 15.8 \\
Total & 76 & 32.9 \\
\hline
\end{tabular}

ate whereas only $9.5 \%$ see it as completely inappropriate. Table 4.13B shows the translation given by Pickthall, 'who possess dignity and easy'.25\% of the respondents rate it as completely inappropriate and only $9.2 \%$ of them see it as completely appropriate. Table $4.13 \mathrm{C}$ shows the translation given by Shakir, 'who possess grace abundance'.25\% of the respondents think it is completely appropriate and $11.5 \%$ of them think it is completely inappropriate. Table 4.13D shows the translation given by Qaribullah, 'who possess dignity and plenty swear'.18.4\% of the participants see it as completely inappropriate while $10.5 \%$ of them see it as completely appropriate. Table4.13E shows the translation given by Sale 'who possess an abundance of wealth'.32.9\% of the participants think it is completely appropriate while only $5.3 \%$ of them think it is completely inappropriate.

Table 4.14 above shows the mean scores, standard deviation and the rank ordering of the third meaning of the word 'alfadl'. The mean scores were compared and ranked ordered according to the lowest and highest mean scores. The difference between the two translations is not significant. The next lowest mean score was assigned to the translation of Qaribullah $(\mathrm{M}=2.87)$. Accordingly, the difference between the two translations is not significant. The lowest mean score after the translation of Qaribullah was received by the translation of Shakir $(\mathrm{M}=3.30)$. There is no significant relation between the translation of Shakir and Yusuf Ali's. As to the third meaning of the word 'alfadl', the lowest mean score was assigned to Sale's translation $(\mathrm{M}=3.45)$. The difference between the two translation is not significant. All the translations according to this result are the same in terms of their appropriateness. The fourth meaning of the word 'alfadl' is translated as 'grace a bounding', 'infinite bounty', 'mighty grace', 'great favor' and 'great bounty'.

Tables 4.15A, 4.15.B, 4.15.C,4.15D and 4.15E) above show the different translation of the fourth meaning of the word 'alfadl'. Table4.15A shows the translation given by Yusuf Ali 'grace abounding' $21.1 \%$ of the participant think that it is completely appropriate and $10.5 \%$ of them think it is completely inappropriate. Table $4.15 \mathrm{~B}$ shows the translation given by Pickthall 'infinite bounty' $35.5 \%$ of the respondents see it as appropriate while only $5.3 \%$ of them see it as completely inappropriate. Table $4.15 \mathrm{C}$ shows the translation given by Shakir 'mighty grace'.32.9\% of the participants 
Table 4.14. Mean scores, standard deviations and rank ordering of all translations of the third meaning of the word 'alfadl'

\begin{tabular}{lcccc}
\hline Translations & N & Mean & $\begin{array}{c}\text { Standard } \\
\text { deviation }\end{array}$ & $\begin{array}{c}\text { Rank } \\
\text { order }\end{array}$ \\
\hline Yusuf Ali & 76 & 3.4737 & 1.39019 & 1 \\
Pickthall & 76 & 2.6579 & 1.27072 & 5 \\
Shakir & 76 & 3.3026 & 1.36645 & 3 \\
Qaribullah & 76 & 2.8684 & 1.25796 & 4 \\
Sale & 76 & 3.4474 & 1.33061 & 2 \\
Valid N (listwise) & 76 & & & \\
\hline
\end{tabular}

Table 4.15A. Frequencies and percentages of Yusuf Ali's translation of the fourth meaning of the word 'alfadl'

\begin{tabular}{lcc}
\hline \multicolumn{3}{c}{ Item } \\
\hline Grace abounding \\
\hline Completely inappropriate & Frequency & Percent \\
2 & 8 & 10.5 \\
3 & 16 & 21.1 \\
4 & 26 & 34.2 \\
Completely appropriate & 10 & 13.2 \\
Total & 16 & 21.1 \\
\hline
\end{tabular}

Table 4.15B. Frequencies and percentages of Pickthall's translation for the fourth meaning of the word 'alfadl'

\begin{tabular}{lcc}
\hline \multicolumn{3}{c}{ Item } \\
\hline \multicolumn{3}{c}{ Infinite bounty } \\
\hline Scale & Frequency & Percent \\
\hline Completely inappropriate & 4 & 5.3 \\
2 & 24 & 31.6 \\
3 & 12 & 15.8 \\
4 & 9 & 11.8 \\
Completely appropriate & 27 & 35.5 \\
Total & 76 & 100.0 \\
\hline
\end{tabular}

see it as completely appropriate and $9.2 \%$ of them see it as completely inappropriate. Table $4.15 \mathrm{D}$ shows the translation given by Qaribullah 'great favor'.17.1\% of the respondents think it is completely appropriate and $13.2 \%$ of them as completely inappropriate. Table4.15E shows the translation given by Sale 'great beneficence'.19.7\% of the participants see it as completely inappropriate while $18.4 \%$ of them see it as completely appropriate.

Table 4.16 shows the mean score, standard deviations and rank ordering of all the translations for the fourth meaning of the word 'alfadl'. The lowest mean scores are compared and rank ordered. The lowest mean score was received Sale's translation $(\mathrm{M}=2.84)$ while the highest one scored by Pickthall translation $(\mathrm{M}=3.41)$. Accordingly, the difference between these two translations is not significant. The next
Table 4.15C. Frequencies and percentages of Shakir's translation for the fourth meaning of the word 'alfadl'

\begin{tabular}{lcc}
\hline \multicolumn{3}{c}{ Item } \\
\hline Mighty grace \\
\hline Completely inappropriate & Frequency & Percent \\
2 & 7 & 9.2 \\
3 & 15 & 19.7 \\
4 & 19 & 25.0 \\
Completely appropriate & 10 & 13.2 \\
Total & 25 & 32.9 \\
\hline
\end{tabular}

Table 4.15D. Frequencies and percentages of Qaribullah's translation of the fourth meaning of the word 'alfadl'

\begin{tabular}{lcc}
\hline \multicolumn{3}{c}{ Item } \\
\hline Great favor \\
\hline Completely inappropriate & Frequency & Percent \\
2 & 13 & 17.1 \\
3 & 18 & 23.7 \\
4 & 17 & 22.4 \\
Completely appropriate & 18 & 23.7 \\
Total & 10 & 13.2 \\
\hline
\end{tabular}

Table 4.15E. Frequencies and percentages of Sale's translation for the fourth meaning of the word 'alfadl'

\begin{tabular}{lcc}
\hline \multicolumn{3}{c}{ Item } \\
\hline Gcale & Frequency & Percent \\
\hline Completely inappropriate & 15 & 19.7 \\
2 & 22 & 28.9 \\
3 & 13 & 17.1 \\
4 & 12 & 15.8 \\
Completely appropriate & 14 & 18.4 \\
Total & 76 & 100.0 \\
\hline
\end{tabular}

Table 4.16. Mean scores, standard deviations and the rank ordering of all translations for the fourth meaning of the word 'alfadl'

\begin{tabular}{lcccc}
\hline Translation & N & Mean & $\begin{array}{c}\text { Standard } \\
\text { deviation }\end{array}$ & $\begin{array}{c}\text { Rank } \\
\text { order }\end{array}$ \\
\hline Yusuf Ali & 76 & 3.1316 & 1.26851 & 2 \\
Pickthall & 76 & 3.4079 & 1.38735 & 1 \\
Shakir & 76 & 3.4079 & 1.36799 & 1 \\
Qaribullah & 76 & 2.9211 & 1.30398 & 3 \\
Sale & 76 & 2.8421 & 1.40525 & 4 \\
Valid N (listwise) & 76 & & & \\
\hline
\end{tabular}


lowest mean score was scored by Qaribullah's translation $(M=2.92)$. The difference between the two translations is not significant. The translation of Yusuf Ali received the next mean score $(M=3.13)$. Consequently, the relation between the two translations is not significant. The lowest mean score was assigned to Shakir translation $(\mathrm{M}=3.24))$. There is thus a significant difference between the two translations.

\section{FINDINGS}

\section{Summary}

This study attempted to look into the lexical choices of the translation of the Qur'an. It was planned to find out whether these lexical choices affect the meaning and accordingly the readers' understanding. There were 76 participants constituted the final sample of this responded to the questionnaire (Arabic-English questionnaire). The presentation of the data (part 4) included a great deal of discussion. Thus, in this concluding chapter a summary of the findings, conclusion, recommendations and suggestions will be presented. The responses of the 76 participants to an 18-item questionnaire (Arabic-English questionnaire) have been tabulated and examined as shown in Appendix I.

The data analysis presented in part 4 revealed that the native speakers translators were linguistically equal to non- native speakers and vise versa. This is confirmed by the rank ordering of the five translations. The first position was assigned to Yusuf Ali while both the native speakers occupied the second and third positions consecutively. This also indicates that the linguistic factor is of great importance in the translation process. Moreover, the translators' attitude plays no role in the translation process or in the translators' performance as in the case of Sale.

It is also confirmed that there are differences in conception (frame knowledge) between the Arab and native speakers. These differences are oppositeness, generality complementarities and some cultural concepts differences. These differences can affect the readers' understanding.

According to the above results the hypotheses of the study are confirmed.

The first hypothesis is, "There are differences in conceptions (frame knowledge) between Arabic and English languages". However, many of the respondents of the second questionnaire (word association) did not give free associations and accordingly the result is limited, but at least there are noticeable differences in conception (frame knowledge) between the two languages speakers. The differences are oppositeness, generality complementarities in addition to some cultural differences.

The second hypothesis is, "Different English frames lead to problems in the translation of the Holy Qur'an". The difference in the frame knowledge of the native speakers' translations is not acute. They are almost equal. It is not a problem at least for the 2 words which are the subjects of the present study.

The third hypothesis is, "There are some strategies that the translator uses to overcome these problems". The translators give general English meaning and at the same time give several words or one phrase to translate a single Arabic word.

The fourth hypothesis is, "There are factors that contribute more to the translators' ability (linguistic background/cultural knowledge". The ranking of the five translations showed that the native speakers' linguistics knowledge resulted in good translation irrespective of the negative attitudes towards Islam (as in the case of Sale) and the cultural background as in the case of (Sale and Pickthall) who converted to Islam.

Some participants gave their own translations for some of the words in the first questionnaire. They ranked the translation and at the same time they added their own translations. The most frequent words given other translation by the respondents were 'assalam' in the first position 'Alqa elykum assalam' translated as 'greeting' and 'assalam' in the third position 'Dar assalam' translated as 'paradise'.

It is clear that these 2 words chosen to base this study on are not representative of the whole translation and they are limited to this study.

\section{Implications of the study}

The results of this study have implications for research on the translation of the Qur'an.

1. The extensive literature review of the translation of the Qur'an may encourage further correlation and empirical investigation of effective ways for translating the Holy Qur'an.

2. This present study has given direction to subsequent research by building a corpus of classical Arabic which can be used in investigating lexical problems as compared to other language corpuses.

3. It is recommending "Frame Semantics" theory as a good solution to the translation problems. This may encourage translators and researchers to investigate more about this theory so as to use it in and improve their translations.

4. This study introduces three differences in conception (frame knowledge) between Arabs and native speakers which may give other researchers the opportunity to carry on further investigations.

5. Yusuf Ali's translation was found to occupy the first rank (completely appropriate) among the five translations that were used in this study. This translation has been adopted and reprinted by the Saudi government and this supports and confirms it as participants' best choice.

6. Pickthall's translation was assigned to the second position in the rank ordering. This implies that there are some translations by Western translators need to be known and spread.

7. Sale's translation was assigned the third rank although he had been accused of being anti-Islam. This may indicate that negative attitudes do not affect the translators' performance.

\section{Recommendations}

In the light of the findings' of this study the researchers would recommend that: 
1. Translators should focus on the linguistic background rather than on the cultural knowledge.

2. Tanslators should be aware of the difference in conception between Arabic and English language while translating the Qur'an.

3. The translators should use strategies to avoid problems in the translation process in the Qur'an translation due to the conception difference.

4. The different English frames should not affect the translator's performance in the translation process.

5. Tanslators should use the theory of frame semantics for a better translation.

6. Yusuf Ali and Pickthall's translations are good translations and can be propagated all over the world especially in non-Arabic speaking countries.

7. Pickthall's translation should be made known as a good translation given by an English native speaker.

\section{CONCLUSION}

There are differences in conception (frame knowledge) between Arabs and English native speakers. These differences are oppositeness, generality and complimentary differences. The existence of such differences confirms the first hypothesis. The different English frames are not acute for the native speaker translators. Thus, the second hypothesis is disconfirmed. The use of some strategies by the translators in avoiding problems in the translation process verifies the third hypothesis. The linguistic background contributes more in the translation process than the cultural knowledge and this confirms the fourth and the last hypothesis. The judgment which can be drawn from this conclusion is that, the lexical choices in the translation process of the Qur'an translation affect the translators' performance and consequently the readers' understanding.

\section{Suggestions for Further Studies}

Certain shortcomings of this study are due to that the study has performed on only 2 words. In order to avoid the problems in the English translation of the Qur'an, it is suggested to:

a. investigate the linguistic factor/factors which affect the translation of Holy Qur'an.

b. include other words or a complete chapter of the Qur'an.

c. compare between the early commentators' interpretations and the recent translations of the Qur'an should be carried out.

d. look into the effect of the negative attitudes of the western translators in the translation of the Qur'an.

c. compare between the early commentators' interpretations and the recent translations of the Qur'an should be carried out.

d. look into the effect of the negative attitudes of the western translators in the translation of the Qur'an.

e. Evaluate the performance of Arabs' translators which influences the western readers' understanding. f. compare the problems that influence the translation of the Qur'an performed by Arabs and Western translators.

g. working as a team, translators can back each other to make appropriate choice of translation.

\section{END NOTES}

1. Sunna: A group of Muslims who follow of the model of Prophet Mohammed.

2. Shi'a: A group of Muslims who believe that Ali the prophet's son-in-law was designated by Mohammed to be a leader with special wisdom.

3. Sufi: A group of Muslims who follow the inner, mystical dimension of Islam.

(See Woodhead 2002 and Cudsi 1981).

\section{REFERENCES}

Abdelwali, M. (2007). The loss in the translation of the Qur'an. 11(2). http://accurapid.com/journals/40quran. htm. Retrieved on 9/10/2008.

Adrienne, L., and Keith, L. (1970). Theory of Learning by Prentice-Hall, Inc. Englewood Cliffs.

Albusairi M. (2000). Certain Applications of Linguistics to Translation and Lexicography. Beirut: The Holy Qur'an publishing house.

Ali, A.Y. (1983). The Holy Qur'an: Text, Translation and commentary. Marland.Amana Corp. Beirut: The Holy Qur'an publishing house.

A. Yusuf, A. (1934). The Holy Qur'an Translation Commentary. Beirut: The Holy Qur'an publishing house.

Alston, W. (1943). Philosophy of Language. Englewood cliffs: Prentice-Hall,USA.

Baker, M. (1992). In other words: course book on translation. London and New York: Routledg.

Cramer, D. (1994). Introducing Statistics for Social Research. London and New York: Routledge.

Fillmore.C. (1985). Frames and Semantics of understanding. Quaderni di Semantica, 5 (2), 222-254.

Geeraerts, D. (1992). 'The Semantic Structure of Dutchover.' Leuvense bijdragen 81, 205-30.

Geeraerts, D. (2002). The theoretical and descriptive development of lexical semantics. The lexicon in focus. Competition and convergence in current lexicology, 23-42.

Irving, T.B. (1985). The Qur'an: Text, Translation and Commentary. Marland-Amana Corp.

Issues in Pragmatics (PLIN 3001).

Jeony-Ho, C. (2000). The Implication of Frame Semantics for Translations, 1.2.

Pickthall, M. (1969). The Qur'an: The First American Translation. Bratleboro: Amana Books.

Raof, A. (2001). Qur'an Translation Culture and Civilization in the Middle East. Routedge, UK.

Raof, H. (2001). Qur'an Translation: Discourse, Texture and Exegesis. Routedge, UK.

Sale, G. (---). George Sale Quran Translation. http://www.mlivo. com/translation/sale $\% 20$ George.htm retrieved on 3/3/2008. 


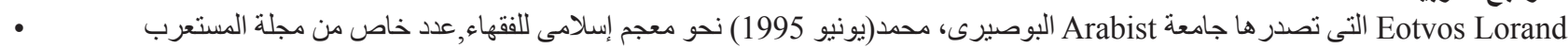
بإنجلتر Leeds بالمجر وجامعة التونة

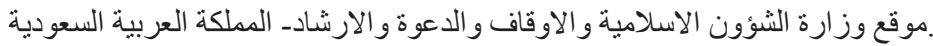
http://guran.al-islam.com/arb/Qsearch/hits.asp?1

\section{APPENDIX}

This questionnaire will be used only for this research project. In each Qur'anic verse in the questionnaire there is an underlined word or expression which is accompanied by a number of translations. For EACH of these translations, please indicate how appropriate you feel it is, using the 5 point scale provided. Thus, if you find a translation completely appropriate, tick the box under 1 (completely appropriate); if you find it completely inappropriate, tick the box under 5 (completely inappropriate); and if it's somewhere in between, choose between 2, 3, or 4, depending on your judgment." If you have another alternative for any of these translations, please write it on the line below the table.

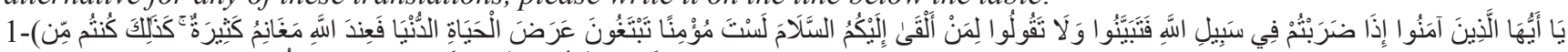

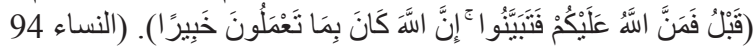

\begin{tabular}{llllll}
\hline Meaning & 1 Completely appropriate & $\mathbf{2}$ & $\mathbf{3}$ & $\mathbf{4}$ & 5 Completely inappropriate \\
\hline 1- Who offers you salutation & & & & & \\
2- Who offereth you peace & & & & \\
3- Who saluteth you & & & \\
\hline
\end{tabular}

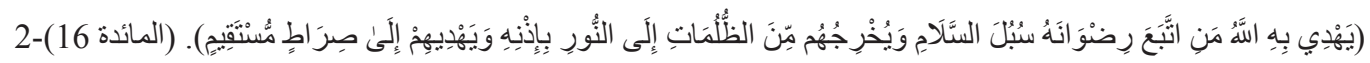

\begin{tabular}{llllll}
\hline Meaning & 1 Completely appropriate & $\mathbf{2}$ & $\mathbf{3}$ & $\mathbf{4}$ & $\mathbf{5}$ Completely inappropriate \\
\hline 1- Ways of peace and safety & & & & & \\
2- Paths of peace & & & & & \\
3- Ways of safety & & & & \\
\hline
\end{tabular}

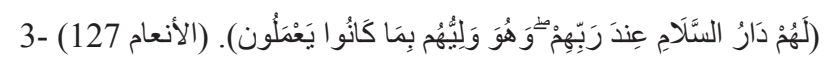

\begin{tabular}{llllll}
\hline Meaning & $\mathbf{1}$ Completely appropriate & $\mathbf{2}$ & $\mathbf{3}$ & $\mathbf{4}$ & $\mathbf{5}$ Completely inappropriate \\
\hline 1- Home of peace & & & & & \\
2- Abode of peace & & & & \\
3- Dwelling of peace & & & \\
\hline
\end{tabular}

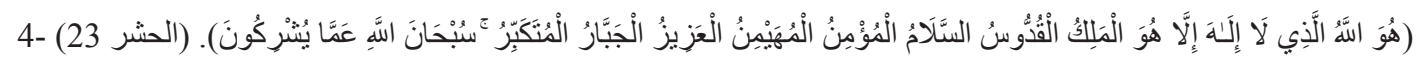

\begin{tabular}{llllll}
\hline Meaning & 1 Completely appropriate & $\mathbf{2}$ & $\mathbf{3}$ & $\mathbf{4}$ & $\mathbf{5}$ Completely inappropriate \\
\hline 1- The source of peace and perfection & & & & & \\
2- Peace & & & & \\
3- The Giver of peace & & & \\
4- The peace &
\end{tabular}

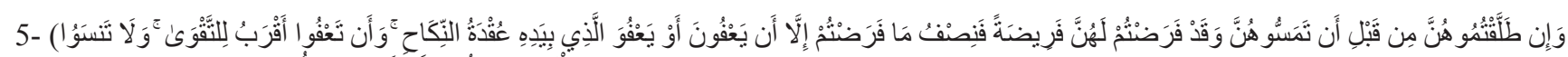

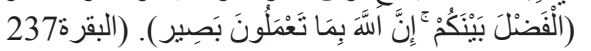

\begin{tabular}{llllll}
\hline Meaning & 1 Completely appropriate & $\mathbf{2}$ & $\mathbf{3}$ & $\mathbf{4}$ & $\mathbf{5}$ Completely inappropriate \\
\hline 1- Liberality & & & & & \\
2- Kindness & & & & \\
3- Giving of free gift & & & & \\
4- Generosity & & & & \\
\hline
\end{tabular}




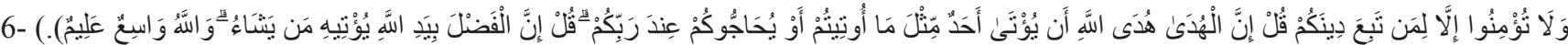
73 (آل عمران (ل)

\begin{tabular}{llllll}
\hline Meaning & $\mathbf{1}$ Completely appropriate & $\mathbf{2}$ & $\mathbf{3}$ & $\mathbf{4}$ & $\mathbf{5}$ Completely inappropriate \\
\hline 1- All bounties & & & & & \\
2- The bounty & & & & \\
3-Grace & & & & \\
4- Excellence & & & & \\
\hline
\end{tabular}

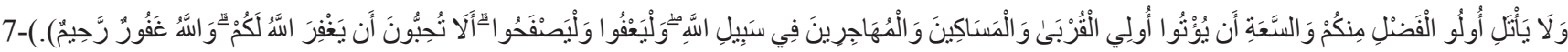
22) (النور)

\begin{tabular}{llllll}
\hline Meaning & 1 Completely appropriate & $\mathbf{2}$ & $\mathbf{3}$ & $\mathbf{4}$ & 5 Completely inappropriate \\
\hline 1- Who possess grace and amplitude of means & & & & \\
2- Who possess dignity and ease & & & \\
3- Who possess grace and abundance & & & \\
4- Who possess bounty and plenty swear & & & \\
5- Who possess abundance of wealth & & & \\
\hline
\end{tabular}

8)

\begin{tabular}{|c|c|c|c|c|c|}
\hline Meaning & 1 Completely appropriate & 2 & 3 & 4 & 5 Completely inappropriate \\
\hline \multicolumn{6}{|l|}{ 1- Grace abounding } \\
\hline \multicolumn{6}{|l|}{ 2- Infinite bounty } \\
\hline \multicolumn{6}{|l|}{ 3- Mighty grace } \\
\hline \multicolumn{6}{|l|}{ 4- Great favor } \\
\hline 5- Great beneficence & & & & & \\
\hline
\end{tabular}

Author Query???

AQ1: Kindly cite tables 4.5 C, 4.10 in the text part 